\title{
Transcriptional study reveals a potential leptin-dependent gene regulatory network in zebrafish brain
}

\author{
Ehsan Pashay Ahi · Emmanouil Tsakoumis • \\ Mathilde Brunel $\cdot$ Monika Schmitz
}

Received: 15 December 2020 / Accepted: 12 May 2021 / Published online: 8 July 2021

(C) The Author(s) 2021

\begin{abstract}
The signal mediated by leptin hormone and its receptor is a major regulator of body weight, food intake and metabolism. In mammals and many teleost fish species, leptin has an anorexigenic role and inhibits food intake by influencing the appetite centres in the hypothalamus. However, the regulatory connections between leptin and downstream genes mediating its appetite-regulating effects are still not fully explored in teleost fish. In this study, we used a loss of function leptin receptor zebrafish mutant and real-time quantitative PCR to assess brain expression patterns of several previously identified anorexigenic genes
\end{abstract}

\section{E. P. Ahi · E. Tsakoumis · M. Schmitz $(\bowtie)$}

Department of Organismal Biology, Comparative Physiology, Evolutionary Biology Centre, Uppsala University, Norbyvägen 18A, SE-752 36 Uppsala, Sweden e-mail: monika.schmitz@ebc.uu.se

E. P. Ahi

e-mail: ehsan.pashay.ahi@ebc.uu.se

E. Tsakoumis

e-mail: manolis.tsakoumis@ebc.uu.se

\section{E. P. Ahi}

Organismal and Evolutionary Biology Research Programme, University of Helsinki, Viikinkaari 9, 00014 Helsinki, Finland

\section{Brunel}

Department of Molecular Sciences, Swedish

University of Agricultural Sciences, Allmas Allé 5,

SE-750 07 Uppsala, Sweden

e-mail: mathilde.brunel@slu.se downstream of leptin signal under different feeding conditions (normal feeding, 7-day fasting, 2 and 6-h refeeding). These downstream factors include members of cart genes, $c r h b$ and $g n r h 2$, as well as selected genes co-expressed with them based on a zebrafish co-expression database. Here, we found a potential gene expression network (GRN) comprising the abovementioned genes by a stepwise approach of identifying co-expression modules and predicting their upstream regulators. Among the transcription factors (TFs) predicted as potential upstream regulators of this GRN, we found expression pattern of $s p 3 a$ to be correlated with transcriptional changes of the downstream gene network. Interestingly, the expression and transcriptional activity of $S p 3$ orthologous gene in mammals have already been implicated to be under the influence of leptin signal. These findings suggest a potentially conserved regulatory connection between leptin and $s p 3 a$, which is predicted to act as a transcriptional driver of a downstream gene network in the zebrafish brain.

Keywords Leptin receptor - Zebrafish $\cdot$ Gene expression $\cdot$ Gene regulatory network $\cdot$ Feeding · Brain

\section{Introduction}

Feeding behaviour is controlled by processes involving appetitive behaviours (hunger-driven activities) 
and food ingestion (Keen-Rhinehart et al. 2013). The central regulation of feeding behaviour in brain (hypothalamus region) is influenced by endocrine signals, which are triggered after exposure to different metabolic and nutritional conditions. The neurons mediating the appetite-regulating effects, so called accurate nucleus neurons in mammals (Opazo et al. 2019), are located in the periventricular and lateral parts of the hypothalamus in fish (Jeong et al. 2018). These neurons can be classified into two main types: orexigenic, stimulating food intake and/or locomotor activity, and anorexigenic, reducing food intake and/or locomotor activity (Sohn 2015). The appetite-regulation genes are the major player in these processes, and to this date, a range of neuropeptides and their cognate receptors encoded by these genes are identified in fish (Volkoff 2016). These genes can also be categorised based on their orexigenic and anorexigenic functions (Arora and Anubhuti 2006; Parker and Bloom 2012). Despite recent advances in understanding the functions of these genes in controlling appetite, little is known about their transcriptional regulatory connections under different feeding conditions in fish.

In mammals, leptin has been shown to be an upstream transcriptional stimulator of several anorexigenic genes in the brain, such as Cart, Crh, Mc4r, POMC (Schwartz et al. 1996; Thornton et al. 1997; Ghamari-Langroudi et al. 2011; Lee et al. 2013), suggesting that leptin mediates its effects on feeding behaviour through induction of these genes in the brain. However, in fish, similar positive regulatory connections have only recently been reported between leptin signal and transcription of these anorexigenic genes in zebrafish (Ahi et al. 2019a). In general, little is known about leptin-dependent regulatory mechanisms in fish and previous attempts to reveal the complexity of leptin mediated transcriptional regulation of biological processes have mainly addressed its other physiological roles (e.g. its role in mechanisms controlling fish reproduction (Paolucci et al. 2020; Wang et al. 2020)).

The leptin-dependent phenotypic effects on fish growth remain still controversial. In medaka, a loss of function mutation in leptin receptor (lepr) has shown to increase food intake and growth rate at the post-juvenile stage (Chisada et al. 2014). In zebrafish, however, while a loss of function mutation in lepa (one of the two genes encoding leptin) causes similar effects such as increased weight and length under normal feeding condition (Audira et al. 2018), different mutations in the lepr gene result in controversial phenotypes (Michel et al. 2016; Fei et al. 2017). For example, with a mutation causing a premature termination codon in lepr, the adult zebrafish did not exhibit any growth changes under normal feeding and overfeeding conditions (Michel et al. 2016). Whereas when introducing a 17 bp deletion in lepr gene, the adult zebrafish showed increased weight under overfeeding conditions (Fei et al. 2017).

In our previous study, we found no phenotypic difference under normal feeding condition, using a different loss of function zebrafish lepr mutant (Ahi et al. 2019a). However, based on our recent observations, the same zebrafish lepr mutant showed significant increase in length and weight under overfeeding (unpublished data). At transcriptional level, we found decreased expression of several anorexigenic genes in the brain of zebrafish carrying a non-functional mutant of leptin receptor gene (Ahi et al. 2019a). Among these anorexigenic genes, we found consistent reduced expression of all the cocaine- and amphetamine-regulated transcripts, cart genes, as well as their potential downstream target gene, $c r h b$ (corticotropin-releasing hormone), in the leptin receptor mutant $\left(\mathrm{lepr}^{-/-}\right)$at normal feeding condition (Ahi et al. 2019a). The anorexigenic role of cart genes is suggested in zebrafish (Nishio et al. 2012; Guillot et al. 2016) and other teleost fishes (Volkoff 2016). However, not all cart genes have similar expression distribution in the zebrafish brain, and they do not follow similar expression patterns in response to changes in feeding conditions suggesting a complex expression regulation (Akash et al. 2014). In goldfish, another member of Cypriniformes, only cartl inhibition of feeding is regulated by leptin in the brain (Volkoff and Peter 2001). A similar regulatory connection between cart and leptin is also observed in an evolutionary distant catfish species (Subhedar et al. 2011). Therefore, our finding of similar expression changes of all cart genes in response to the absence of leptin signal suggests the potential existence of a shared leptin-dependent upstream regulator in the zebrafish brain. On the other hand, the similar expression differences of $c r h b$, which also has anorexigenic effects in fish (De Pedro et al. 1993; Bernier 2006), confirms potential regulatory connections between cart genes and crhb in zebrafish brain, as observed both in mammalian and 
avian brains (Sarkar et al. 2004; Smith et al. 2004; Mo et al. 2015). Furthermore, the decreased expression of $c r h b$ was accompanied with reduced expression of gnrh2, a member of gonadotropin-releasing hormones with anorexigenic function in zebrafish and goldfish brain (Hoskins et al. 2008; Nishiguchi et al. 2012). Interestingly, gnrh2 is shown to be a direct downstream target of $c r h$ in goldfish (Kang et al. 2011) and similar expression patterns of $c r h$ and gnrh2 in response to feeding were recently reported in another Cypriniformes species (Schizothorax davidi) (Yuan et al. 2021). These suggest the presence of a potentially conserved cart-crhb-gnrh2 regulatory axis at downstream of the leptin signal in zebrafish brain (Ahi et al. 2019a). Nevertheless, the detailed regulatory mechanisms linking the expression of cart, crhb and gnrh2 genes as well as their connection to leptin signal remain unclear in vertebrates.

With the advent of ever-growing databases for gene co-expression networks in a variety of organisms, including zebrafish (e.g. see (Obayashi et al. 2019)), as well as prediction tools for transcription factor binding sites (e.g. TRANSFAC (Matys et al. 2003)), it becomes possible to identify gene regulatory networks through examining the expression of members of a predicted network. In this study, we aimed to investigate the existence of potential GRN(s) containing cart, crh and gnrh2 genes, which can be controlled by leptin signal in zebrafish brain under different feeding conditions. For this, we followed a simple stepwise gene detection approach using qPCR in order to deduce GRNs involved in various biological processes in fish (Ahi et al. 2015; Ahi and Sefc 2018). Based on this approach, we used a zebrafish co-expression database to select the top ranked co-expressed genes with our genes of interest (cart, crh and gnrh2) to assess their expression pattern by qPCR. We first identified gene modules coexpressed with cart, crh and gnrh2 genes, and next we predicted their potential upstream transcriptional regulators. Based on our gene expression results, we predicted GRNs, at downstream of leptin signals in zebrafish brain, which might be affected by changes in feeding and contribute to leptin-dependent metabolic and behavioural effects. Our findings provide first evidence for environmentally influenced GRNs, which might be directly controlled by leptin signalling in the brain of a vertebrate species.

\section{Methods}

\section{Zebrafish husbandry}

Zebrafish belonging to the strain LepR Sa12953 were obtained from the European Zebrafish Resource Centre. The mutation of the lepr gene was created by the Sanger Institute for the Zebrafish Mutation Project, replacing a thymine with an adenine on chromosome 6 , resulting in a premature stop codon and thus to a shortened polypeptide. Wild-type and lepr mutant zebrafish of similar age were kept in 3-1 recirculating tanks, under an artificial photoperiod of 14/10 light/ dark conditions at $28.4{ }^{\circ} \mathrm{C}$ at the Genome Engineering Zebrafish National Facility at Uppsala University (or SciLife lab).

Experimental set-up and sampling of tissues

Detailed description of the experimental set-up can be found in Ahi et al. (2019a). Briefly, siblings wild-type and lepr mutant zebrafish fish were randomly selected at the beginning of the experiment from different stock tanks of fish and put in a 3-1 tank together for each genotype and for each feeding category: fish fed normally (control group); fish fasted for a week; fish fasted for a week and sampled $2 \mathrm{~h}$ after refeeding; and fish fasted for a week and sampled $6 \mathrm{~h}$ after refeeding (Supplementary data 1). Each 3-1 tank contained 5 fish with mix female/male ratios (1-2 females and 3-4 males) depending on the numbers of males and females available for each genotype at that moment. Tanks were placed next to each other and were connected to the same water system, indicating that the water parameters were exactly the same for all tanks as well as the sanitary measures taken to avoid diseases (filters and UV light). The water flow was set at the same speed manually for each tank and light conditions were comparable for all tanks as they were located at the same place. Water parameters were regularly monitored by the facility staff. Specifically, water temperature $\left({ }^{\circ} \mathrm{C}\right), \mathrm{pH}$ and conductivity $(\mu \mathrm{S} / \mathrm{cm})$ were measured daily, while general hardness $\left({ }^{\circ} \mathrm{dGH}\right)$ and carbonate hardness $\left({ }^{\circ} \mathrm{dKH}\right)$, as well as the levels of ammonia ( $\mathrm{NH} 4, \mathrm{mg} / \mathrm{l})$, nitrites $\left(\mathrm{NO}_{2}, \mathrm{mg} / \mathrm{l}\right)$ and nitrates $\left(\mathrm{NO}_{3}, \mathrm{mg} / \mathrm{l}\right)$ were measured bi-weekly.

During the experiment, fish were fed once a day with dry pellets (morning) and twice with Artemia 
(middays and evenings). No significant differences were observed in the standard body length, the net weight and the hepato-somatic index (HSI) between the two genotypes (Supplementary data 1). During the sampling, fish were first anaesthetized by immersion in a $0.4 \mathrm{mg} / \mathrm{ml}$ Tricaine (MS-222) solution and euthanatized by immersion in ice bath. Zebrafish were decapitated, their brains were carefully dissected, transferred into $200 \mu \mathrm{l}$ RNAlater RNA extraction stabilisation solution (Ambion Inc., Austin, TX) and stored at $4{ }^{\circ} \mathrm{C}$ for $24 \mathrm{~h}$ and then at $-20{ }^{\circ} \mathrm{C}$ until the RNA isolation step.

\section{RNA isolation and cDNA synthesis}

The total RNA of the sampled brain tissues was extracted using Trizol (Ambion), according to the manufacturer's protocol. Briefly, the dissected brains were removed from RNAlater and were homogenised in $200 \mu \mathrm{l}$ Trizol, with a fine syringe needle (25G Terumo needle and BD Plastipak 1-ml syringe). Once they were thoroughly homogenised, $40 \mu \mathrm{l}$ of chloroform (Sigma-Aldrich) were added to each sample, followed by a 5-min incubation in room temperature and a centrifugation at $12,000 \mathrm{~g} / \mathrm{min}$ for $20 \mathrm{~min}$ at $4{ }^{\circ} \mathrm{C}$. The aqueous upper phase was then carefully transferred into new RNAse-free tubes, in which $1 \mu \mathrm{l}$ of glycoblue (Ambion) and $100 \mu \mathrm{l}$ of ice cold $\left(-20{ }^{\circ} \mathrm{C}\right)$ isopropyl alcohol (Sigma-Aldrich) were added directly. Samples were mixed rigorously, incubated for $5 \mathrm{~min}$ at room temperature and then centrifuged at $13,000 \mathrm{~g} / \mathrm{min}$ for $20 \mathrm{~min}$ at $4{ }^{\circ} \mathrm{C}$. The supernatants were discarded and the RNA pellets were washed three times with $200 \mu \mathrm{l}$ of ice cold $\left(-20{ }^{\circ} \mathrm{C}\right) 75 \%$ ethanol solution (VWR) by centrifugation at $9000 \mathrm{~g} / \mathrm{min}$ for $5 \mathrm{~min}$ at $4{ }^{\circ} \mathrm{C}$. The RNA pellets were dried under the fume hood for $10 \mathrm{~min}$ at room temperature and were solubilised, by adding $10 \mu \mathrm{l}$ of nuclease-free water (Ambion). All the RNA samples were afterwards DNAse treated, to remove any genomic DNA contamination, using the Turbo DNA-free kit (Ambion), according to the manufacturer's instructions. The quantity and quality of the final RNA samples were measured spectrophotometrically, using NanoDrop (Thermo-Fisher Scientific). cDNA synthesis was carried out by reverse transcription (RT) with $1000 \mathrm{ng}$ of RNA input from each sample. Specifically, $0.5 \mu \mathrm{l}$ of random primers $(50 \mathrm{ng} / \mu \mathrm{l})$ and $0.5 \mu \mathrm{lNTP}(10 \mathrm{nM})$ were added in each RNA sample, following an incubation at $65{ }^{\circ} \mathrm{C}$ for $5 \mathrm{~min}$ and then the samples were cooled down on ice for $1 \mathrm{~min}$. A total mix of $3.5 \mu \mathrm{l}$, containing $2 \mu \mathrm{l}$ of $5 X$ First-Strand Buffer, $0.5 \mu \mathrm{l}$ of DTT $(0.1 \mathrm{M}), 0.5 \mu \mathrm{l}$ of RNase OUT (40 U/ $\mu \mathrm{l}$ ) and $0.5 \mu \mathrm{l}$ of Superscript III RT (200 U/ $\mu \mathrm{l})$, was prepared and added to each sample. The thermal profile of the RT was $25^{\circ} \mathrm{C}$ for $5 \mathrm{~min}, 50{ }^{\circ} \mathrm{C}$ for $50 \mathrm{~min}$ and $70{ }^{\circ} \mathrm{C}$ for $15 \mathrm{~min}$. The final volume of $10 \mu \mathrm{l}$ of cDNA from each sample was stored at $-20{ }^{\circ} \mathrm{C}$ until further analysis.

Gene selection, primer design and qPCR

We followed an already described approach of gene regulatory network deduction using zebrafish coexpression data available at COXPRESdb (http:// coxpresdb.jp/) version 7.0 (Obayashi et al. 2019). To do this, we first selected 5 top ranked genes with highest co-expression values with all of the cart genes (cart1-4) in zebrafish, and the same was performed for selection of top 5 genes co-expressed with $\mathrm{crhb}$ and gnrh2. The selection criteria was limited to only the genes with supportability score of 1 as minimum (described in COXPRESdb (Obayashi et al. 2019)) (Supplementary data 1). Among the selected candidate genes, those showing expression differences similar to cart genes (first co-expression module) or to $c r h b$ (second co-expression module) were chosen for the next step of upstream regulator prediction. We performed motif enrichment on $4-\mathrm{kb}$ upstream sequences (promoter and 5'-UTR) of these genes (for the identified genes in each module separately) using MEME algorithm (Bailey et al. 2009). The overrepresented motifs in the promoters of the genes were compared to position weight matrices (PWMs) obtained from the TRANSFAC database (Matys et al. 2003) using STAMP (Mahony and Benos 2007) to identify potential transcription factor (TF) binding sites.

Specific primers for each target and reference gene were designed, based on the genes sequences obtained from Blastn through a zebrafish database engine (zfin.org) (Howe et al. 2013). The sequences were imported to the CLC Genomic Workbench (CLC Bio, Denmark), and the exon/exon boundaries were tracked using the annotated Danio rerio genome in the Ensembl database (Flicek et al. 2012). Primers with short amplicon sizes $(<200 \mathrm{bp})$ were designed using the Primer Express 3.0 software (Applied Biosystems, CA, USA) and their dimerization and 
secondary structure formation were lastly evaluated using OligoAnalyzer 3.1 (Integrated DNA Technology) (Supplementary data 1).

Relative gene expression levels were measured by quantitative polymerase chain reaction (qPCR) on a MxPro-3000 PCR machine (Stratagene, La Jolla, CA), using the MxPro software (Stratagene) for data mining. For qPCR assays, $1 \mu \mathrm{l}$ of diluted cDNA of each sample was mixed with $7.5 \mu \mathrm{l}$ of qPCR PowerUp SYBR Green Master mix (Thermo-Fisher Scientific), $0.3 \mu \mathrm{l}$ of forward and reverse primers $(10 \mu \mathrm{M})$ and $6.2 \mu \mathrm{l}$ of RNA-free water in a total volume of $15 \mu \mathrm{l}$. Each biological replicate was tested in two technical replicates for each gene, followed by a sample maximisation method (Bustin et al. 2009), aiming to have an optimal experimental set-up in each run. The thermal profile of the qPCR assays was $50{ }^{\circ} \mathrm{C}$ for $2 \mathrm{~min}$ (1 cycle), $95{ }^{\circ} \mathrm{C}$ for $2 \mathrm{~min}$ ( 1 cycle), $95{ }^{\circ} \mathrm{C}$ for $15 \mathrm{~s}$ and $62{ }^{\circ} \mathrm{C}$ for $1 \mathrm{~min}$ (40 cycles). A dissociation step $\left(60-95{ }^{\circ} \mathrm{C}\right)$ was also performed after the amplification step, to verify the specificity of the product. For the calculation of the primer efficiencies, standard curves were generated using serial dilutions of pooled cDNA of random samples obtained from the RT step and were tested in three technical replicates. Standard curves were calculated using the following formula: $\mathrm{E}=10[-1 /$ slope $] . \mathrm{R}^{2}$ values were higher than 0.990 and efficiencies were ranging between 94 and 108\% for all assays (Supplementary data 1).

\section{Gene expression analysis}

In this study, we used the $\mathrm{Cq}$ values of a validated reference gene, glucose-6-phosphate dehydrogenase $(g 6 p d)$, showing stable brain expression across both genotypes and different feeding conditions to normalise $\mathrm{Cq}$ values of target genes for each sample $(\Delta \mathrm{C}$ $\mathrm{q}_{\text {target }}=\mathrm{Cq}_{\text {target }}-\mathrm{Cq}_{\text {reference }}$ ) (Ahi et al. 2019a). We selected a biological replicate with lowest expression (highest $\mathrm{Cq}$ value) for each gene and then used the following formula; $\Delta \mathrm{Cq}_{\text {target }}-\Delta \mathrm{Cq}_{\text {calibrator }}$, in order to calculate $\Delta \Delta \mathrm{Cq}$ values. The relative expression quantities (RQ values) were calculated as $2^{-\Delta \Delta C q}$ and their logarithmic values (fold changes) were applied for statistical analysis (Pfaffl 2001). Student t-tests were carried out for the direct comparison of the gene expression levels for each target gene between the two genotypes in each feeding condition. Analysis of variance (ANOVA) tests, followed by Tukey's honest significant difference (HSD) post hoc tests, were performed between the different feeding conditions within each genotype, for the analysis of the dynamic expression of the target genes. Benjamini-Hochberg procedure was used to correct the false positive rate in the multiple comparisons (Thissen et al. 2002). In order to search for any similarities in the expression patterns across the feeding conditions in each genotype, we performed pairwise Pearson correlation coefficients. Finally, in order to identify overall similarities between the different feeding conditions and genotypes, we implemented a dendrogram hierarchical clustering of the expression values of the target genes. All statistical analyses were carried out using the R software (http://www.r-project.org) (Team RDC 2013).

\section{Results}

Expression analyses of cart $1-4, c r h b$ and gnrh2 co-expressed genes

In order to identify a gene co-expression module which includes cart genes, we followed a knowledgebased and stepwise approach previously established to identify GRNs linked to phenotypic differences in teleost fish (Ahi et al. 2015; Ahi and Sefc 2018). The first step was to use a zebrafish co-expression database, COXPRESdb (Obayashi et al. 2019), in order to select candidate genes with potential co-regulatory connections to cart genes. To do this, we selected top 5 genes with highest probability of expression correlation with all the four cart genes in zebrafish coexpression database (Supplementary data 1). Expression profiling of these genes within each genotype revealed that in wild-type zebrafish changes in normal feeding conditions (after fasting and refeeding) reduce their expression in the brain and interestingly this pattern was almost lost in the lepr mutant (Fig. 1a). The direct comparison of the two genotypes within each treatment group demonstrated that in the lepr mutant the expression of all 5 genes (ckmt1, pik3ipl, satla.2, agr2 and tcima) is reduced under normal feeding conditions but not after changes in the feeding condition (Fig. 2a and Supplementary data 1). This could imply that fasting and refeeding might trigger other molecular signal(s) which override the leptin-dependent differential regulation of these genes. Although, a 
a

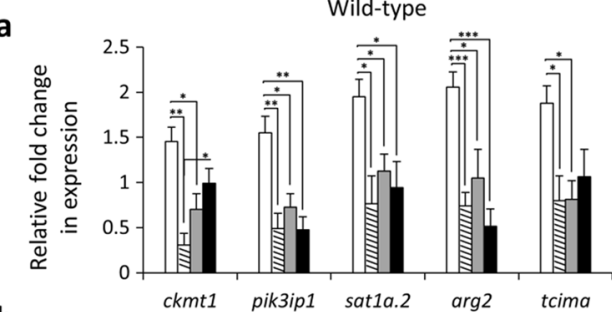

b
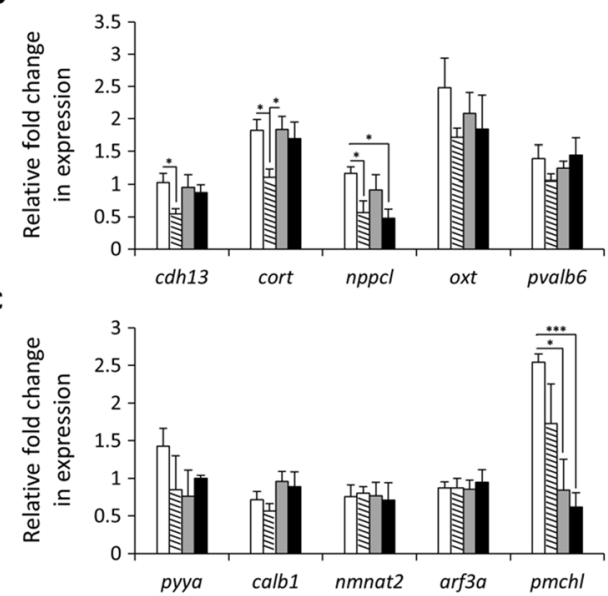

Fig. 1 Expression dynamics of selected co-expressed genes within each genotype during the fasting-refeeding experiment. Expression changes of (a) cart-co-expressed genes, (b) crhbco-expressed genes and (c) gnrh2-co-expressed genes within

higher number of samples are required to assure that the absence of the signal is because of the increase of variation in response to fasting or of the existence of an overriding signal triggered by fasting. It should be noted that the expression dynamics of the 5 cartco-expressed genes were similar to the expression patterns of cart genes under similar conditions, i.e. reduced expression in the lepr mutant in the normal feeding group (Ahi et al. 2019a). This suggests potential co-regulatory connections between cart genes and the 5 selected co-expressed genes as predicted in COXPRESdb (Obayashi et al. 2019).

We also conducted the same approach to identify $c r h b$ co-expressed genes by selecting top 5 genes with highest probability of expression correlation with $c r h b$ in zebrafish database. We found 3 genes, $c d h 13$, cort and nppcl, with reduced expression (similar to $c r h b$ ) in fasting group compared to the control group in wild-type, and such expression pattern was not present in lepr mutant (Fig. 1b). The direct comparison of the two genotypes within each treatment group
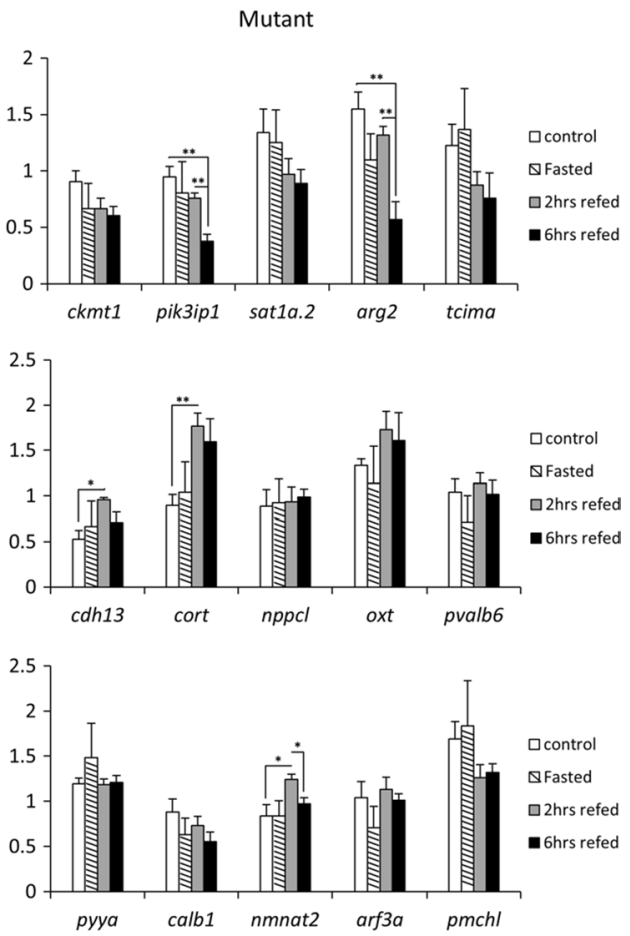

each genotype. Means and standard errors of fold changes in expression of five biological replicates are shown for each experimental group. Significant differences are indicated by asterisks $(* P<0.05$; $* * P<0.01 ; * * * P<0.001)$

showed that again only 3 genes, cdh13, cort and oxt (but not $n p p c l$ ), had higher expression in wild-type than the mutant zebrafish under normal feeding condition (control group) (Fig. 2b). Altogether, these findings indicate that the 4 genes $c d h 13$, cort, nppcl and oxt show similar expression pattern to $c r h b$ as identified in our previous study (Ahi et al. 2019a), suggesting that partial co-regulatory connections between $c r h b$ and the selected co-expressed genes have been retained in zebrafish brain.

Finally, after applying the same approach for gnrh2 co-expressed genes (the top 5 genes based on the zebrafish database), only one of the genes, pmchl, showed fairly similar expression pattern to gnrh2 in the wild-type group (Fig. 1c). The same gene also showed higher expression in wild-type compared to the mutant under normal feeding condition (Fig. 2c). This suggests that only the co-regulatory connection between gnrh 2 and pmchl out of the top 5 selected co-expressed genes has been retained in the zebrafish brain. 
a

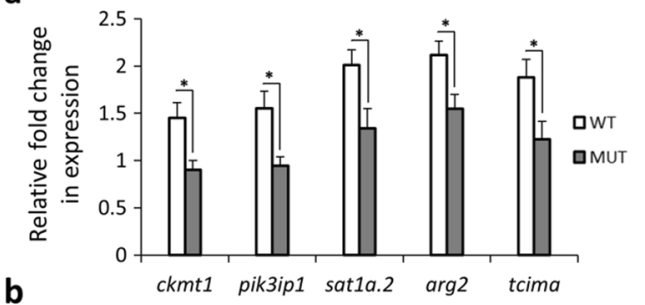

b

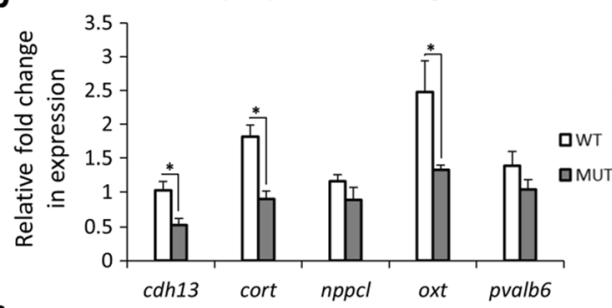

C

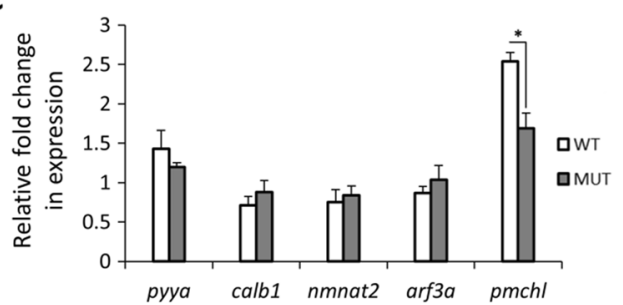

Fig. 2 Gene expression differences between the two genotypes, wild-type (WT) and lepr mutant, at normal feeding condition. (a-c) Differential expression of genes co-expressed with cart 1-4, crhb and gnrh2. (d-f) Predicted TFs at upstream

Expression analyses of predicted upstream regulators of the co-expression modules

In a next step, we searched for potential upstream regulators of each of the identified gene co-expression modules through prediction of TF binding sites in the upstream regulatory sequences of the co-expressed genes. For the cart co-expression module, we used promoter and 5'-UTR sequences of all cart genes and the 5 validated co-expressed genes (ckmtl, pik3ipl, satla2, arg2 and tcima) for motif enrichment analysis step. We found 6 motifs present in the regulatory sequences of these genes (Table 1) and after parsing the motifs against the vertebrate TF binding sites, we listed top matched TF(s) for each motif (Table 1). Similarly, we retrieved the regulatory sequences of crhb and 4 of its co-expressed genes cdh13, cort, nppcl and oxt. The enrichment analysis yielded 5 motifs which could be matched to TF binding sites as listed in Table 1. Finally, the analysis on the regulatory sequences of gnrh2 and pmchl identified 4 d
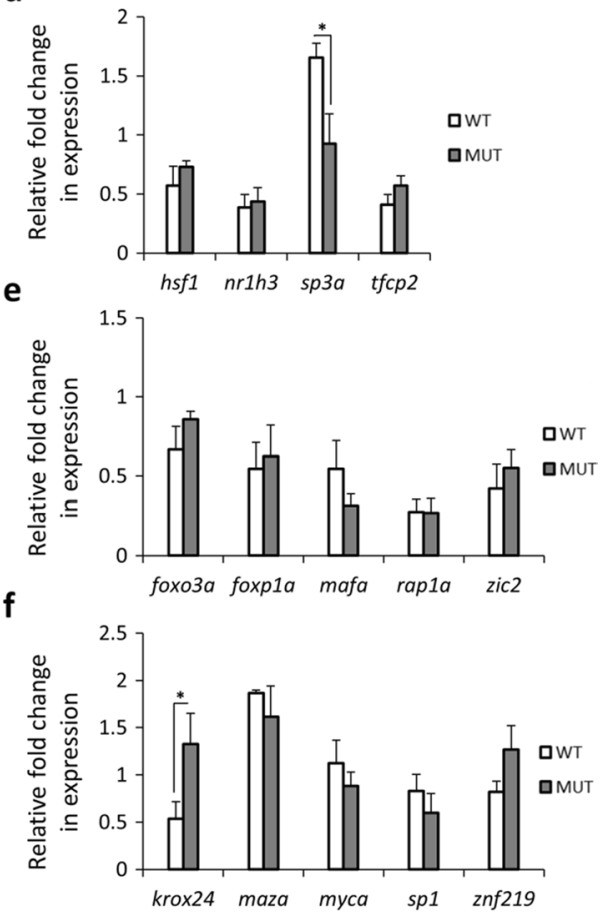

of cart1-4, crhb and gnrh2 co-expressed modules. Means and standard errors of fold changes in expression of five biological replicates are shown for each experimental group. Significant differences are indicated by asterisks $(* P<0.05)$

motifs, which could be matched to 6 TF binding sites (Table 1). Only one of the TF binding sites, FOXP1, was shared between the predicted upstream TFs of cart and crhb co-expression modules. On the other hand between gnrh2 and crhb co-expression modules only RAP1 binding site was found to be shared.

The expression analysis of potential upstream TFs of cart co-expression module revealed that 3 of the TFs, $h s f l, n r l h 3$ and $t f c p 2$, had similar expression pattern in both genotypes under different feeding conditions with increased expression during refeeding (Fig. 3a). However, only one of the TFs, sp3a, followed an expression pattern similar to genes in cart co-expression module with higher expression in the control group than the fasting group. Furthermore, in the direct comparison of the genotypes, $s p 3 a$ was the only TF that showed higher expression in wild-type than the mutant in the control group (Fig. 2d). These findings suggest that $s p 3 a$ might act as an upstream transcriptional regulator of cart co-expression module and its expression is under the influence of leptin 
Table 1 Predicted TF binding sites for potential upstream regulators of the three gene coexpression modules. PWD ID indicates positional weight matrix ID of a predicted binding site and E-values refer to matching similarity between the pre- dicted motif sequences and the PWD IDs. The count implies on number of genes in each network containing the predicted motif sequence on their regulatory region

\begin{tabular}{|c|c|c|c|c|c|}
\hline & TF binding site & PWM ID & Count & Predicted motif sequence & E-value \\
\hline \multirow[t]{7}{*}{ cart network } & LXR (Nr1h3) & M00766 & $9 / 9$ & CRCCCGBMDGAAACCCACVCAMACGCASSGAG & $5.00 \mathrm{E}-09$ \\
\hline & FOXP1 & M00987 & $9 / 9$ & AWAWAWATAWATAWATAAATAAATAAAW & $1.39 \mathrm{E}-08$ \\
\hline & AIRE & M00999 & $9 / 9$ & AWAWAWATAWATAWATAAATAAATAAAW & $1.70 \mathrm{E}-08$ \\
\hline & AIRE & M01000 & $8 / 9$ & TYATTTTATTTATTKTAHATTWTTTTTGT & $3.03 \mathrm{E}-08$ \\
\hline & SP3 & M00665 & $9 / 9$ & CMMTTKGASAGGKCAKWGG & $1.67 \mathrm{E}-07$ \\
\hline & TFCP2 (LSF) & M00947 & $7 / 9$ & CTGRCCYAGMCKSGGCTSRARCCAGYGAC & $7.26 \mathrm{E}-07$ \\
\hline & HSF1 & M00163 & $9 / 9$ & TTYHTTCATTTTCTTTTSBKT & $9.09 \mathrm{E}-07$ \\
\hline \multirow[t]{5}{*}{ crh network } & ZIC2 & M00449 & $4 / 5$ & GGGGYGGTACC & $8.65 \mathrm{E}-07$ \\
\hline & FOXO3 & M00477 & $5 / 5$ & TBCTTTGKCTWCATA & $1.73 \mathrm{E}-06$ \\
\hline & MAF & M00648 & $5 / 5$ & СССМААСВYСМСТYКВКМСТG & $2.00 \mathrm{E}-06$ \\
\hline & RAP1 & M00213 & $5 / 5$ & GTGTGTGBGT & $3.27 \mathrm{E}-06$ \\
\hline & FOXP1 & M00987 & $5 / 5$ & ACACACACRCACACACAWVKG & $8.60 \mathrm{E}-06$ \\
\hline \multirow[t]{6}{*}{ gnrh2 network } & MAZ & M00649 & $2 / 2$ & GGRAGGGG & $1.90 \mathrm{E}-09$ \\
\hline & SP1 & M00931 & $2 / 2$ & GGRAGGGG & $4.32 \mathrm{E}-08$ \\
\hline & ZNF219 & M01122 & $2 / 2$ & CCAYCMCSSYCCMCC & $6.66 \mathrm{E}-08$ \\
\hline & KROX & M00982 & $2 / 2$ & CCAYCMCSSYCCMCC & $9.33 \mathrm{E}-08$ \\
\hline & c-MYC & M00123 & $2 / 2$ & CAAAGACATGYGGTACAGGTGAAWTGGGTRKGC & $1.53 \mathrm{E}-07$ \\
\hline & RAP1 & M00213 & $2 / 2$ & TGTGTRTGKATGT & $1.81 \mathrm{E}-07$ \\
\hline
\end{tabular}

signal during normal feeding condition. The expression profiling of predicted TFs upstream of crhb co-expression module did not reveal any $\mathrm{TF}$ with similar expression patterns compared to members of the module (Fig. 3b). Instead, all the predicted TFs showed increased expression during refeeding in both genotypes. The direct comparison of the two genotypes within the normal feeding group revealed no expression differences (Fig. 2e). Altogether, the inconsistent expression patterns of predicted TFs and the genes in crhb co-expression module raise the possibility that the genes in this module are regulated indirectly through interaction with other upstream regulators than the TFs with binding sites on their regulatory sequences. Among the predicted upstream TFs of gnrh 2 co-expression module, 3 of the TFs, krox 24, myca and spl, had differences in expression pattern within each genotype (Fig. 3c). However, the direct comparison of the two genotypes in the normal feeding group revealed expression difference for only krox 24 , higher expression in the mutant than the wild-type (Fig. 2f). This suggests potential inhibitory effects of krox 24 on transcription of gnrh 2 and pmchl in zebrafish brain at normal feeding condition.
Expression correlation analyses revealing a gene regulatory network

Within each genotype, we performed pairwise expression correlation analysis between cart, crhb and gnrh 2 co-expressed genes, and two of their predicted upstream regulators, krox 24 and $s p 3 a$, in order to identify potential regulatory connections between them (Ahi and Sefc 2018). In both genotypes, almost all of the observed correlations appeared to be positive; however, not all of the positive correlations were similar between the genotypes and many of the positive correlations were lost in the mutant with impaired leptin signal (Fig. 4a). For example, in the wild-type, all of the cart genes showed positive expression correlations with the selected cart co-expressed genes forming a complete co-expression module (Fig. 4a). Whereas, in the lepr mutant almost all of the positive expression correlations between cart genes and their selected co-expressed genes were lost (except for satla2) indicating potentially weakened co-regulatory connections between them and loss of the coexpression module (Fig. 4a). Among all the predicted upstream regulators, only krox 24 and sp $3 a$ had shown 
a

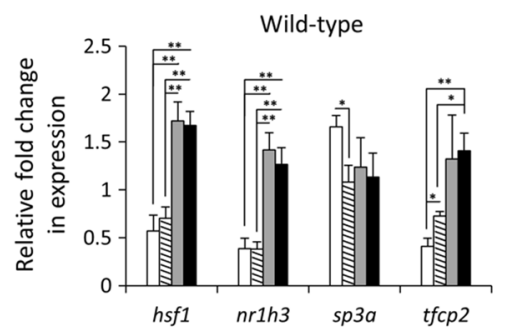

b

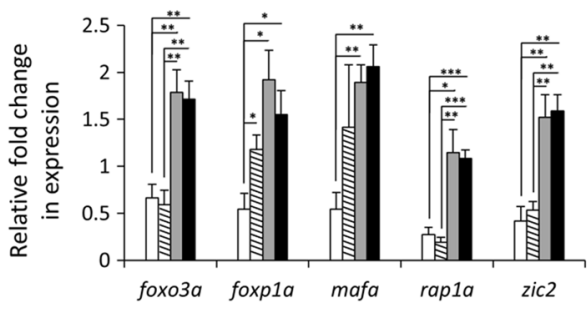

c

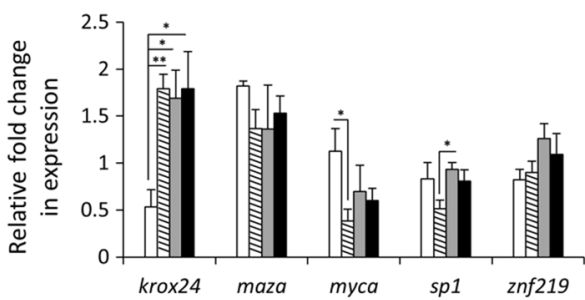

Fig. 3 Expression dynamics of predicted upstream regulators of the co-expressed genes within each genotype during the fasting-refeeding experiment. Expression changes of predicted TFs at upstream of (a) cart-co-expressed genes, (b) crhb-coexpressed genes and (c) gnrh2-coexpressed genes within each
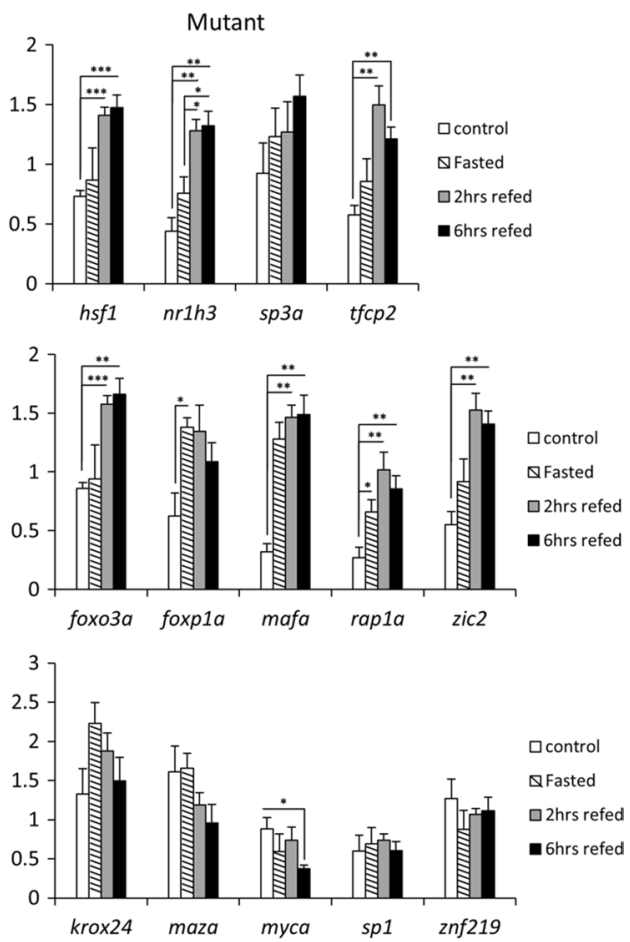

genotype. Means and standard errors of fold changes in expression of five biological replicates are shown for each experimental group. Significant differences are indicated by asterisks $(* P<0.05 ; * * P<0.01 ; * * * P<0.001)$

all of the cart genes (cocaine- and amphetamineregulated transcripts) between the wild-type and lepr mutant. All the four cart genes showed reduced brain expression after changes in feeding condition but only in the wild-type zebrafish (Ahi et al. 2019a). We demonstrated that fasting reduces the expression of all the cart genes in the brain and their expression reduction maintains during short-term refeeding period (i.e. $2 \mathrm{~h}$ and $6 \mathrm{~h}$ after refeeding). This is in agreement with the conserved anorexigenic role of cart genes shown in zebrafish (Nishio et al. 2012; Guillot et al. 2016). It appeared that these transcriptional changes were dependent on a functional leptin signal, raising the question, what potential regulatory network(s) link these processes. In goldfish brain, the cartl mediated inhibition of feeding is regulated by leptin signal (Volkoff and Peter 2001), indicating a conserved regulatory connection between active leptin signal and transcription of cart genes in both zebrafish and goldfish. The leptin-dependent transcriptional regulation

the consistent and similar expression differences for 
a

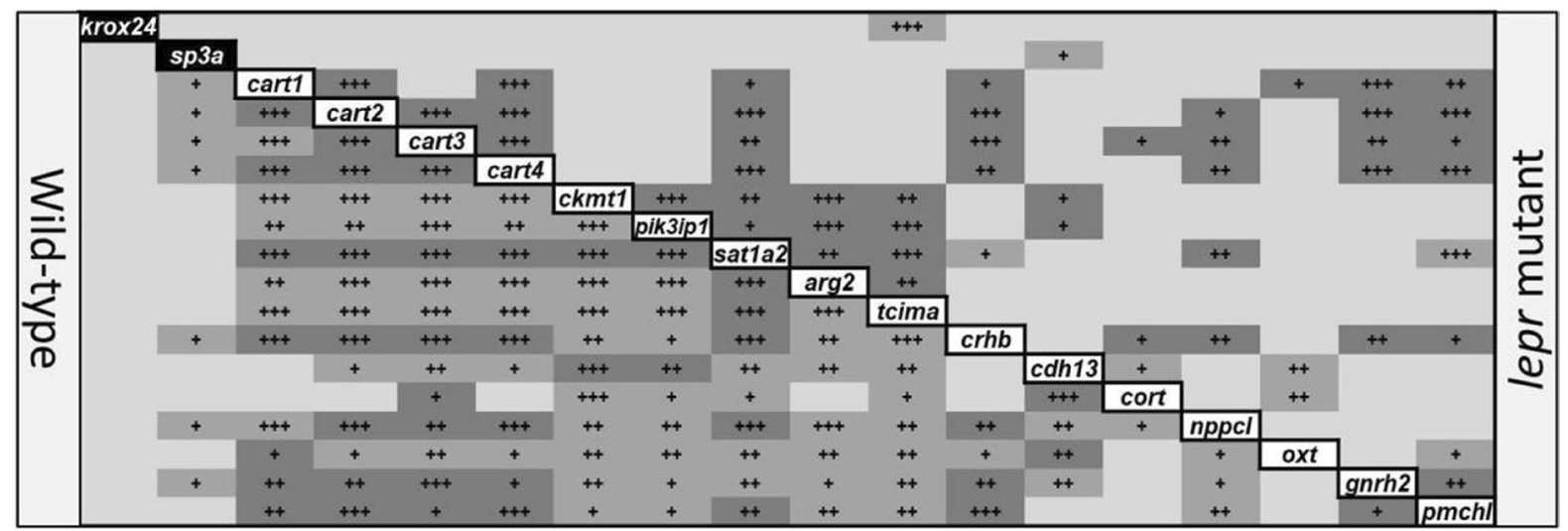

b

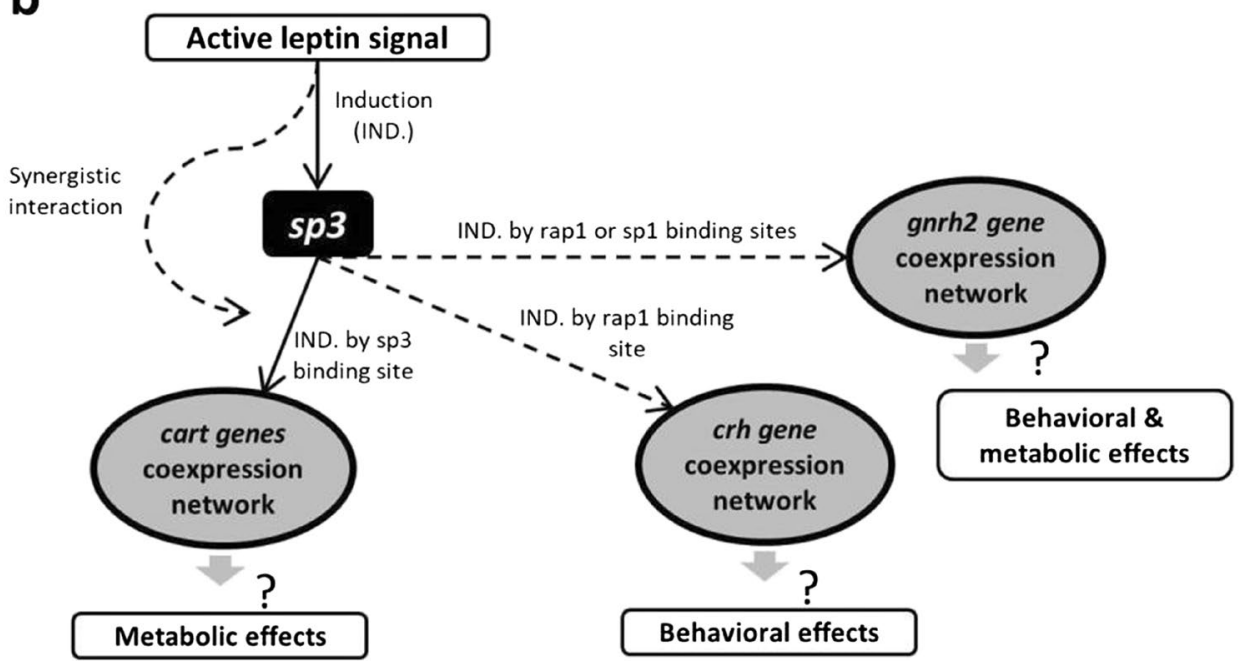

Fig. 4 Expression correlations of cart, crhb and gnrh2 related gene regulatory networks and their potential regulatory connections. (a) Pairwise expression correlations between the members of the cart related gene regulatory network in the brain of wild-type and lepr mutant zebrafish in the fastingrefeeding experiment. The plus signs indicate positive Pearson

of cart genes seems to be a conserved mechanism in vertebrates, as observed in rodents, where leptin administration increases the brain expression of Cart1 gene (Lee et al. 2013) and non-functional leptin signal leads to absence of Cartl expression in the brain (Kristensen et al. 1998).

In addition, similar expression patterns to cart genes were also observed for two other anorexigenic genes, crhb (corticotropin-releasing hormone) (De Pedro et al. 1993; Bernier 2006) and gnrh2 (gonadotropin-releasing hormone 2) (Hoskins et al. 2008; correlation coefficients, and 1 to 3 signs represent significant levels of $P<0.05, P<0.01$ and $P<0.001$. The pairwise correlations delineated with black borders are similar between the two genotypes. (b) A schematic illustration of a potential regulatory interaction between leptin signal and cart-/crh-/gnrh2coexpression modules mediated by $s p 3 a$ in zebrafish brain

Nishiguchi et al. 2012), suggesting regulatory connections between cart genes, crhb and gnrh2 in zebrafish brain. In mammals and birds, it had been demonstrated that $C R H$ and $C A R T 1$ have transcriptional regulatory connections; however, the details of these regulatory mechanisms still remained unclear (Sarkar et al. 2004; Smith et al. 2004; Mo et al. 2015). $C R H$ has been shown to act downstream of activated leptin signal in rat and its brain expression increased after leptin administration (Schwartz et al. 1996). Similarly, the cart-dependent regulation of Gnrh 
secretion by activated leptin signal had been demonstrated in rat brain as well (Lebrethon et al. 2000; Parent et al. 2000). Moreover, in Sander lucioperca, a perciform fish species, it is shown that leptin induces the brain expression of gnrh2 (Schaefer and Wuertz 2016), and in goldfish, gnrh2 has been reported to be a downstream transcriptional target of $c r h$ (Kang et al. 2011). In response to feeding, crh and gnrh2 have been recently reported to have similar expression patterns in Schizothorax davidi (another Cypriniformes species) (Yuan et al. 2021). However, other anorexigenic genes were also found showing strong response to feeding, which can be independent of leptin mediated transcriptional regulation (Yuan et al. 2020).

In this study, we set out a stepwise approach with the aim of unravelling potential regulatory connections by which leptin signal can control the expression of cart, crhb and gnrh2 genes in zebrafish brain. We have already established this approach using qPCR analysis, co-expression databases and de novo prediction of TF binding sites to identify GRNs underlying different biological processes such as musculoskeletal morphogenesis, pigmentation and regeneration in teleost fish (Ahi and Sefc 2017, 2018; Ahi et al. 2019b).

We identified 5 genes co-expressed with all the cart genes making a network of co-regulated genes with reduced expression after changes in feeding condition in only wild-type group. Among these genes, ckmt1, satla. 2 and arg2 have been shown to be expressed in the brain of zebrafish (Singh et al. 2010; Drew et al. 2012; Lien et al. 2013) and mouse (Yu et al. 2001; Yang et al. 2008; Pfefferle et al. 2011; St-Amand et al. 2012). Ckmtl encodes a creatine kinase required for the transfer of high energy phosphate from mitochondria to the cytosolic carrier (creatine), spermidine N1-acetyltransferase 1, satla.2, encodes an enzyme involved in the catabolic pathway of polyamine metabolism, and arginase 2 encoded by arg 2 is an enzyme catalysing the hydrolysis of arginine to ornithine and urea. However, their potential functions at downstream of leptin signalling and their effects on feeding behaviour have not been studied. A recent study in zebrafish has demonstrated that ckmtl is a transcriptionally responsive gene to feeding with carbohydrate enriched diet (Ma et al. 2020).

Three of the crhb co-expressed genes, chd13, cort and oxt, respectively, encode cadherin-13, cortistatin and oxytocin/isotocin neurophysin, and are expressed in vertebrate brain (Takeuchi and Ohtsuki 2001; Unger and Glasgow 2003; de Lecea 2008; Blechman et al. 2011). Both cort and oxt have overlapping hypothalamus expression in zebrafish (Unger and Glasgow 2003; de Lecea 2008; Blechman et al. 2011), but so far chdl3 expression in the hypothalamus has only been investigated in mammals (Forero et al. 2017; Kiser et al. 2019). Interestingly, all three genes have related functions in their role in vertebrates behaviour, such as effects on locomotor activity and feeding behaviour (Spier and de Lecea 2000; Onaka et al. 2012; King et al. 2017; Kiser et al. 2019). It should be noted that $\mathrm{crh}$ function is also associated with behavioural changes such as increased anxiety-like behaviour, reduced aggressive behaviour, changes in locomotor activity and reduced feeding, which result in anorexigenic action in teleost fish (Matsuda 2013). Interestingly, a study in zebrafish with loss of function in leptin gene (lepa) has shown increased anxiety-like behaviour with reduction in aggressive behaviour (Audira et al. 2018). These findings might indicate that leptin signal exerts its anorexigenic effects on zebrafish behaviour through hierarchical regulation of $c r h b$ co-expression network genes.

Among the top 5 genes co-expressed with gnrh2, we only found one gene, pmchl, to show higher expression level in wild-type than the mutant at normal feeding condition. Pmchl encodes a pro-melanin concentrating hormone-like protein which is expressed together with its paralogous gene (pmch2) in zebrafish hypothalamus (Berman et al. 2009). While the orthologous gene to pmch2 is also present in mammals $(P M C H)$ and has role in appetite regulation, pmchl gene only exists in fish and its potential role in feeding remained unexplored (Berman et al. 2009). However, an expression study of both pmch genes in the brain of the flatfish (Platichthys stellatus) has revealed differential regulation of pmchl between fasting and feeding groups indicating its potential role in appetite regulation in fish (Kang and Kim 2013).

Among the transcription factors (TFs) predicted upstream of the cart-coexpression module, only specificity protein $3 \mathrm{a}, s p 3 a$, has shown expression patterns similar to the co-expressed members of the network with reduced expression during fasting compared to normal feeding condition in wild-type zebrafish (Figs. $2 \mathrm{~d}$ and $3 \mathrm{a}$ ). This suggests that $s p 3 a$ is potentially a direct upstream regulator of the cart-coexpression module. On the other hand, the loss of this pattern in 
the lepr mutant indicates that $s p 3 a$ expression is under the control of leptin signal in zebrafish brain during fasting. sp3a encodes a transcription factor belonging to Sp1 related family genes which can have bi-functional roles in stimulating or repressing the transcription of numerous target genes (Majello et al. 1997). In humans, it has been shown that Sp3 (encoded by an mammalian orthologue of $s p 3 a$ ) and $\mathrm{Sp} 1$ can have synergistic or opposite regulatory effects on transcription, while binding to the same regulatory element upstream of genes playing a role in lipid metabolism and the pathogenesis of obesity in adipose tissues (Barth et al. 2003; Hoffmann et al. 2013). Interestingly, it has already been demonstrated in mammals that leptin signal can enhance the regulatory effects of $\mathrm{Sp} 1$ and Sp3 on the transcription of their target genes (Lin et al. 2006; García-Ruiz et al. 2012). This enhancement in transcriptional regulation can be through leptin-mediated increase in the binding affinity of Sp1 and Sp3 to their regulatory elements on the promoters of their target genes or via direct expression induction of Sp1 and Sp3 by leptin signal (Lin et al. 2006; García-Ruiz et al. 2012). In addition to our results, the findings in mammals imply a potential regulatory axis in which leptin activity is required for $s p 3 a$ expression and subsequently $s p 3 a$ acts as upstream transcriptional regulator of the cart-coexpression module. The potential role of $s p 3 a$ during feeding and appetite regulation has not been investigated. A recent study in zebrafish has demonstrated though that the presence of $\mathrm{sp} 1 / \mathrm{sp} 3$ binding site is essential for transcriptional regulation of elovl5 gene (Goh et al. 2020), which encodes an enzyme involved in diet induced obesity in vertebrates (Wang et al. 2006).

We did not find expression pattern similarities between members of $c r h b$-coexpression module and their predicted upstream TFs (Figs. 2e and 3b). This could indicate that the expression regulation might be mediated indirectly through other TFs or the predicted TFs might acquire different regulatory capability due to post-translational changes. For instance, it has been shown in mice that functional leptin signalling is required for Mafa (V-Maf musculoaponeurotic fibrosarcoma oncogene homolog A), to be capable of nuclear localization (without effects on Mafa expression though) and to exert its transcriptional regulatory effects (Harmon et al. 2009). Since the expression pattern of mafa observed in our study is similar between the two genotypes, it is likely that mafa nuclear localization (rather than its expression) is affected in the absence of leptin signal and thus its potential regulatory effects on $c r h b$-coexpression module are lost. Another potential scenario could be transcriptional regulation of $c r h b$-coexpression module again by $s p 3 a$ (identified as potential upstream regulator of the previous module as described above) through binding to rap1 element at upstream sequences of the members of crhb-coexpression module. Again, the overall expression pattern of rapla is not different between the genotypes, but it is already known that Sp3 and Sp1 can bind to Rap1 binding site in mammals and activate the transcription of Rap1 target genes (Simon et al. 1997).

Among the TFs predicted upstream of gnrh2 and pmchl, we did not find any TF showing similar expression pattern to gnrh2 and pmchl and with higher expression level in wild-type than the mutant at the normal feeding condition (Figs. $2 \mathrm{f}$ and $3 \mathrm{c}$ ). However, we found binding sites for rap1 and $\mathrm{sp} 1$ on the regulatory sequences of both gnrh 2 and pmchl, which might again indicate trans-activation of these genes through sp3a (because of its affinity to bind to both rap1 and sp1 binding sites). Another TF that showed opposite expression pattern to sp3a, gnrh2 and pmchl was krox 24 or egrl (early growth response 1), with higher expression levels in the mutant than wildtype at the normal feeding condition (Figs. $2 \mathrm{f}$ and 3c). In mammals, leptin and Krox24/Egrl are shown to stimulate each other's expression as reciprocal transcriptional regulators (Bjørbæk et al. 2001; de Lartigue et al. 2010; Kim et al. 2019). Interestingly, several studies have already demonstrated that Sp1/Sp3 can compete with Krox24/Egr1 on their binding sites during the transcriptional regulation of their common target genes (Bahouth et al. 1997; Thottassery et al. 1999; Barroso and Santisteban 1999; Du et al. 2000; Tan et al. 2003; Zhang and Liu 2003; Bedadala et al. 2007). This binding competition can be favoured towards transcriptional repression or induction of a target gene following an increase in abundance of Krox24/Egr1 or Sp1/Sp3, respectively. Therefore, the reduced expression of gnrh2 and pmchl in the mutant at normal feeding condition might be a result of increased expression of krox24/egrl which acts as transcriptional repressor. Moreover, it has been recently shown that ghrelin, an antagonist of leptin, can act as an upstream regulator of krox24/egrl in zebrafish brain (Blanco et al. 2020). 
We summarised our results by depicting a potential leptin-dependent gene regulatory network in zebrafish brain, which might be affected by changes in feeding condition (Fig. 4b). However, it is important to note that the current study is conducted with a limited sample size and sex-dependent differences cannot be ruled out. Future studies with larger sample size including enough number of individuals from both sexes as well as overfeeding treatment are required to fully explore the expression dynamic of the potential GRN. Further functional investigations, including high-throughput methods such as transcriptome, can also provide a more comprehensive map of all potential GRNs in zebrafish brain.

\section{Conclusions}

The study provides first evidence for the existence of a complex gene regulatory network in the brain at downstream of leptin signal which is involved in regulation of feeding in zebrafish. This network consists of transcription factors such as sp3a and krox24/egrl and their downstream genes, such as cart gene family, crhb, cort, oxt, pmchl and gnrh2 (forming coexpression modules), which are involved in behavioural and metabolic control of feeding in fish. The impaired leptin signal led to reduced expression of an upstream regulator of the network, $s p 3 a$, which in turn caused reduced expression of the downstream network genes in brain. These regulatory effects seem no longer to be maintained after fasting in zebrafish brain.

Supplementary Information The online version contains supplementary material available at https://doi.org/10.1007/ s10695-021-00967-0.

Acknowledgements The authors thank the SciLife lab zebrafish facility of Uppsala University for its responsible management of our fish. Special thanks to Chrysoula Zalamitsou for her technical assistance through the study. The work was supported by the Carl Trygger Foundation for scientific research (CTS 16:413 and CTS 19:805).

Author contribution All authors contributed to the study conception and design. Material preparation, data collection and analysis were performed by Ehsan Pashay Ahi, Emmanouil Tsakoumis and Mathilde Brunel. The first draft of the manuscript was written by Ehsan Pashay Ahi and Monika Schmitz, and all authors commented on previous versions of the manuscript. All authors read and approved the final manuscript.
Funding Open access funding provided by Uppsala University. The work was supported by the Carl Trygger Foundation for scientific research (CTS 16:413 and CTS 19:805).

Data availability All the data represented in this study are provided within the main manuscript or in the supplementary materials.

\section{Declarations}

Ethics approval The fish handling procedures were approved by the Swedish Ethical Committee on Animal Research in Uppsala (permit C10/16).

Conflict of interest The authors declare no competing interests.

Open Access This article is licensed under a Creative Commons Attribution 4.0 International License, which permits use, sharing, adaptation, distribution and reproduction in any medium or format, as long as you give appropriate credit to the original author(s) and the source, provide a link to the Creative Commons licence, and indicate if changes were made. The images or other third party material in this article are included in the article's Creative Commons licence, unless indicated otherwise in a credit line to the material. If material is not included in the article's Creative Commons licence and your intended use is not permitted by statutory regulation or exceeds the permitted use, you will need to obtain permission directly from the copyright holder. To view a copy of this licence, visit http://creativecommons.org/licenses/by/4.0/.

\section{References}

Ahi EP, Sefc KM (2017) Anterior-posterior gene expression differences in three Lake Malawi cichlid fishes with variation in body stripe orientation. Peer J 5:e4080. https://doi. org/10.7717/peerj.4080

Ahi EP, Sefc KM (2018) Towards a gene regulatory network shaping the fins of the princess cichlid. Sci Rep 8:9602

Ahi EP, Steinhäuser SS, Pálsson A, et al (2015) Differential expression of the aryl hydrocarbon receptor pathway associates with craniofacial polymorphism in sympatric Arctic charr. Evodevo 6. https://doi.org/10.1186/s13227-015-0022-6

Ahi EP, Brunel M, Tsakoumis E, Schmitz M (2019a) Transcriptional study of appetite regulating genes in the brain of zebrafish (Danio rerio) with impaired leptin signalling. Sci Rep 9:20166. https://doi.org/10.1038/s41598-019-56779-z

Ahi EP, Richter F, Lecaudey LA, Sefc KM (2019b) Gene expression profiling suggests differences in molecular mechanisms of fin elongation between cichlid species. Sci Rep 9:9052. https://doi.org/10.1038/s41598-019-45599-w

Akash G, Kaniganti T, Tiwari NK et al (2014) Differential distribution and energy status-dependent regulation of the four CART neuropeptide genes in the zebrafish brain. $\mathrm{J}$ Comp Neurol 522:2266-2285. https://doi.org/10.1002/cne. 23532 
Arora S, Anubhuti (2006) Role of neuropeptides in appetite regulation and obesity - a review. Neuropeptides 40:375401. https://doi.org/10.1016/J.NPEP.2006.07.001

Audira G, Sarasamma S, Chen J-R, et al (2018) Zebrafish mutants carrying leptin a (lepa) gene deficiency display obesity, anxiety, less aggression and fear, and circadian rhythm and color preference dysregulation. Int J Mol Sci 19. https://doi.org/10.3390/ijms 19124038

Bahouth SW, Cui X, Beauchamp MJ et al (1997) Promoter analysis of the rat $\beta 1$-adrenergic receptor gene identifies sequences involved in basal expression. Mol Pharmacol 51:620-629. https://doi.org/10.1124/mol.51.4.620

Bailey TL, Boden M, Buske FA et al (2009) MEME SUITE: tools for motif discovery and searching. Nucleic Acids Res 37:W202-W208. https://doi.org/10.1093/nar/gkp335

Barroso I, Santisteban P (1999) Insulin-induced early growth response gene (Egr-1) mediates a short term repression of rat malic enzyme gene transcription. J Biol Chem 274:17997-18004. https://doi.org/10.1074/jbc.274.25.17997

Barth N, Langmann T, Schölmerich J et al (2003) Identification of regulatory elements in the human adipose most abundant gene transcript-1 (apM-1) promoter: role of SP1/SP3 and TNF-? as regulatory pathways. Diabetologia 1:14251433. https://doi.org/10.1007/s00125-002-0895-5

Bedadala GR, Pinnoji RC, Hsia SCV (2007) Early growth response gene 1 (Egr-1) regulates HSV-1 ICP4 and ICP22 gene expression. Cell Res 17:546-555. https://doi.org/10. 1038/cr.2007.44

Berman JR, Skariah G, Maro GS et al (2009) Characterization of two melanin-concentrating hormone genes in zebrafish reveals evolutionary and physiological links with the mammalian MCH system. J Comp Neurol 517:695-710. https://doi.org/10.1002/cne.22171

Bernier NJ (2006) The corticotropin-releasing factor system as a mediator of the appetite-suppressing effects of stress in fish. Gen Comp Endocrinol 146:45-55. https://doi.org/10. 1016/J.YGCEN.2005.11.016

Bjørbæk C, Buchholz RM, Davis SM et al (2001) Divergent roles of SHP-2 in ERK activation by leptin receptors. J Biol Chem 276:4747-4755. https://doi.org/10.1074/jbc.M007439200

Blanco AM, Cortés R, Bertucci JI et al (2020) Brain transcriptome profile after CRISPR-induced ghrelin mutations in zebrafish. Fish Physiol Biochem 46:1-21. https://doi.org/ 10.1007/s10695-019-00687-6

Blechman J, Amir-Zilberstein L, Gutnick A et al (2011) The metabolic regulator PGC-1 $\alpha$ directly controls the expression of the hypothalamic neuropeptide oxytocin. J Neurosci 31:1483514840. https://doi.org/10.1523/JNEUROSCI.1798-11.2011

Bustin SA, Benes V, Garson JA et al (2009) The MIQE guidelines: minimum information for publication of quantitative real-time PCR experiments. Clin Chem 55:611-622. https://doi.org/10.1373/clinchem.2008.112797

Chisada S, Kurokawa T, Murashita K et al (2014) Leptin receptor-deficient (knockout) medaka, Oryzias latipes, show chronical up-regulated levels of orexigenic neuropeptides, elevated food intake and stage specific effects on growth and fat allocation. Gen Comp Endocrinol 195:9-20. https://doi.org/10.1016/J.YGCEN.2013.10.008

de Lartigue G, Lur G, Dimaline R et al (2010) EGR1 is a target for cooperative interactions between cholecystokinin and leptin, and inhibition by ghrelin, in vagal afferent neurons. Endocrinology 151:3589-3599. https://doi.org/ 10.1210/en.2010-0106

de Lecea L (2008) Cortistatin-functions in the central nervous system. Mol Cell Endocrinol 286:88-95. https://doi. org/10.1016/j.mce.2007.12.014

De Pedro N, Alonso-Gómez AL, Gancedo B et al (1993) Role of corticotropin-releasing factor (CRF) as a food intake regulator in goldfish. Physiol Behav 53:517-520. https://doi.org/10.1016/0031-9384(93)90146-7

Drew RE, Settles ML, Churchill EJ et al (2012) Brain transcriptome variation among behaviorally distinct strains of zebrafish (Danio rerio). BMC Genomics 13:323. https://doi.org/10.1186/1471-2164-13-323

Du B, Fu C, Kent KC et al (2000) Elevated Egr-1 in human atherosclerotic cells transcriptionally represses the transforming growth factor- $\beta$ type II receptor. J Biol Chem 275:3903939047. https://doi.org/10.1074/jbc.M005159200

Fei F, Sun S-Y, Yao Y-X, Xu W (2017) Generation and phenotype analysis of zebrafish mutations of obesity-related genes lepr and mc4r. Acta Physiol Sin 69:61-69

Flicek P, Amode MR, Barrell D et al (2012) Ensembl 2012. Nucleic Acids Res 40:D84-90. https://doi.org/10.1093/ nar/gkr991

Forero A, Rivero O, Wäldchen S et al (2017) Cadherin-13 deficiency increases dorsal raphe 5-HT neuron density and prefrontal cortex innervation in the mouse brain. Front Cell Neurosci 11:307. https://doi.org/10.3389/fncel.2017.00307

García-Ruiz I, Gómez-Izquierdo E, Díaz-Sanjuán T et al (2012) Sp1 and Sp3 transcription factors mediate leptin-induced collagen $\alpha 1$ (I) gene expression in primary culture of male rat hepatic stellate cells. Endocrinology 153:5845-5856. https://doi.org/10.1210/en.2012-1626

Ghamari-Langroudi M, Srisai D, Cone RD (2011) Multinodal regulation of the arcuate/paraventricular nucleus circuit by leptin. Proc Natl Acad Sci U S A 108:355360. https://doi.org/10.1073/pnas.1016785108

Goh PT, Kuah MK, Chew YS et al (2020) The requirements for sterol regulatory element-binding protein (Srebp) and stimulatory protein 1 (Sp1)-binding elements in the transcriptional activation of two freshwater fish Channa striata and Danio rerio elovl5 elongase. Fish Physiol Biochem 46:1349-1359. https://doi.org/10.1007/ s10695-020-00793-w

Guillot R, Cortés R, Navarro S et al (2016) Behind melanocortin antagonist overexpression in the zebrafish brain: a behavioral and transcriptomic approach. Horm Behav 82:87-100. https://doi.org/10.1016/J.YHBEH.2016.04.011

Harmon JS, Bogdani M, Parazzoli SD et al (2009) $\beta$-Cellspecific overexpression of glutathione peroxidase preserves intranuclear MafA and reverses diabetes in $d b / d b$ mice. Endocrinology 150:4855-4862. https://doi.org/10. 1210/en.2009-0708

Hoffmann C, Zimmermann A, Hinney A et al (2013) A novel SP1/SP3 dependent intronic enhancer governing transcription of the UCP3 gene in brown adipocytes. PLoS ONE 8:e83426. https://doi.org/10.1371/journal.pone.0083426

Hoskins LJ, Xu M, Volkoff H (2008) Interactions between gonadotropin-releasing hormone $(\mathrm{GnRH})$ and orexin in the regulation of feeding and reproduction in goldfish (Carassius auratus). Horm Behav 54:379-385. https://doi.org/10. 1016/j.yhbeh.2008.04.011 
Howe DG, Bradford YM, Conlin T et al (2013) ZFIN, the zebrafish model organism database: increased support for mutants and transgenics. Nucleic Acids Res 41:D854D860. https://doi.org/10.1093/nar/gks938

Jeong I, Kim E, Kim S et al (2018) mRNA expression and metabolic regulation of npy and agrp $1 / 2$ in the zebrafish brain. Neurosci Lett 668:73-79. https://doi.org/10.1016/j. neulet.2018.01.017

Kang DY, Kim HC (2013) Functional characterization of two melanin-concentrating hormone genes in the color camouflage, hypermelanosis, and appetite of starry flounder. Gen Comp Endocrinol 189:74-83. https://doi.org/10.1016/j. ygcen.2013.04.025

Kang KS, Shimizu K, Azuma M et al (2011) Gonadotropinreleasing hormone II (GnRH II) mediates the anorexigenic actions of $\alpha$-melanocyte-stimulating hormone ( $\alpha-\mathrm{MSH})$ and corticotropin-releasing hormone $(\mathrm{CRH})$ in goldfish. Peptides 32:31-35. https://doi.org/10.1016/J.PEPTIDES.2010.10.013

Keen-Rhinehart E, Ondek K, Schneider JE (2013) Neuroendocrine regulation of appetitive ingestive behavior. Front Neurosci 7:213. https://doi.org/10.3389/fnins.2013.00213

Kim JH, Jung E, Choi J et al (2019) Leptin is a direct transcriptional target of EGR1 in human breast cancer cells. Mol Biol Rep 46:317-324. https://doi.org/10.1007/ s11033-018-4474-3

King CP, Militello L, Hart A et al (2017) Cdh13 and AdipoQ gene knockout alter instrumental and Pavlovian drug conditioning. Genes, Brain Behav 16:686-698. https://doi. org/10.1111/gbb. 12382

Kiser DP, Popp S, Schmitt-Böhrer AG et al (2019) Early-life stress impairs developmental programming in cadherin 13 (CDH13)-deficient mice. Prog Neuro-Psychopharmacology Biol Psychiatry 89:158-168. https://doi.org/10. 1016/J.PNPBP.2018.08.010

Kristensen P, Judge ME, Thim L et al (1998) Hypothalamic CART is a new anorectic peptide regulated by leptin. Nature 393:72-76. https://doi.org/10.1038/29993

Lebrethon MC, Vandersmissen E, Gérard A et al (2000) In vitro stimulation of the prepubertal rat gonadotropinreleasing hormone pulse generator by leptin and neuropeptide $\mathrm{Y}$ through distinct mechanisms. Endocrinology 141:1464-1469. https://doi.org/10.1210/endo.141.4.7432

Lee SJ, Verma S, Simonds SE et al (2013) Leptin stimulates neuropeptide $\mathrm{Y}$ and cocaine amphetamine-regulated transcript coexpressing neuronal activity in the dorsomedial hypothalamus in diet-induced obese mice. J Neurosci 33:1530615317. https://doi.org/10.1523/JNEUROSCI.0837-13.2013

Lien Y-C, Ou T-Y, Lin Y-T et al (2013) Duplication and diversification of the spermidine/spermine N1-acetyltransferase 1 genes in zebrafish. PLoS ONE 8:e54017. https://doi.org/ 10.1371/journal.pone.0054017

Lin S, Saxena NK, Ding X et al (2006) Leptin increases tissue inhibitor of metalloproteinase I (TIMP-1) gene expression by a specificity protein $1 /$ signal transducer and activator of transcription 3 mechanism. Mol Endocrinol 20:33763388. https://doi.org/10.1210/me.2006-0177

Ma Q, Hu CT, Yue J et al (2020) High-carbohydrate diet promotes the adaptation to acute hypoxia in zebrafish. Fish Physiol Biochem 46:665-679. https://doi.org/10.1007/ s10695-019-00742-2
Mahony S, Benos PV (2007) STAMP: a web tool for exploring DNA-binding motif similarities. Nucleic Acids Res 35:W253-W258. https://doi.org/10.1093/nar/gkm272

Majello B, De Luca P, Lania L (1997) Sp3 is a bifunctional transcription regulator with modular independent activation and repression domains. J Biol Chem 272:40214026. https://doi.org/10.1074/jbc.272.7.4021

Matsuda K (2013) Regulation of feeding behavior and psychomotor activity by corticotropin-releasing hormone (CRH) in fish. Front Neurosci 7:91. https://doi.org/10.3389/fnins. 2013.00091

Matys V, Fricke E, Geffers R et al (2003) TRANSFAC: transcriptional regulation, from patterns to profiles. Nucleic Acids Res 31:374-378

Michel M, Page-McCaw PS, Chen W, Cone RD (2016) Leptin signaling regulates glucose homeostasis, but not adipostasis, in the zebrafish. Proc Natl Acad Sci U S A 113:3084. https://doi.org/10.1073/PNAS.1513212113

Mo C, Cai G, Huang L et al (2015) Corticotropin-releasing hormone (CRH) stimulates cocaine- and amphetamineregulated transcript gene (CART1) expression through CRH type 1 receptor (CRHR1) in chicken anterior pituitary. Mol Cell Endocrinol 417:166-177. https://doi.org/ 10.1016/J.MCE.2015.09.007

Nishiguchi R, Azuma M, Yokobori E et al (2012) Gonadotropin-releasing hormone 2 suppresses food intake in the zebrafish. Danio Rerio Front Endocrinol (lausanne) 3:122. https://doi.org/10.3389/fendo.2012.00122

Nishio S-I, Gibert Y, Berekelya L et al (2012) Fasting induces CART down-regulation in the zebrafish nervous system in a cannabinoid receptor 1-dependent manner. Mol Endocrinol 26:1316-1326. https://doi.org/10.1210/me.2011-1180

Obayashi T, Kagaya Y, Aoki Y et al (2019) COXPRESdb v7: a gene coexpression database for 11 animal species supported by 23 coexpression platforms for technical evaluation and evolutionary inference. Nucleic Acids Res 47:D55-D62. https://doi.org/10.1093/nar/gky1155

Onaka T, Takayanagi Y, Yoshida M (2012) Roles of oxytocin neurones in the control of stress, energy metabolism, and social behaviour. J Neuroendocrinol 24:587-598. https:// doi.org/10.1111/j.1365-2826.2012.02300.x

Opazo R, Plaza-Parrochia F, Cardoso dos Santos GR et al (2019) Fasting upregulates npy, agrp, and ghsr without increasing ghrelin levels in zebrafish (Danio rerio) larvae. Front Physiol 9:1901. https://doi.org/10.3389/fphys.2018.01901

Paolucci M, Coccia E, Imperatore R, Varricchio E (2020) A cross-talk between leptin and $17 \beta$-estradiol in vitellogenin synthesis in rainbow trout Oncorhynchus mykiss liver. Fish Physiol Biochem 46:331-344. https://doi.org/10. 1007/s10695-019-00720-8

Parent AS, Lebrethon MC, Gérard A et al (2000) Leptin effects on pulsatile gonadotropin releasing hormone secretion from the adult rat hypothalamus and interaction with cocaine and amphetamine regulated transcript peptide and neuropeptide Y. Regul Pept 92:17-24

Parker JA, Bloom SR (2012) Hypothalamic neuropeptides and the regulation of appetite. Neuropharmacology 63:18-30. https://doi.org/10.1016/J.NEUROPHARM.2012.02.004

Pfaffl MW (2001) A new mathematical model for relative quantification in real-time RT-PCR. Nucleic Acids Res 29:e45 
Pfefferle AD, Warner LR, Wang CW et al (2011) Comparative expression analysis of the phosphocreatine circuit in extant primates: implications for human brain evolution. J Hum Evol 60:205-212. https://doi.org/10.1016/J. JHEVOL.2010.10.004

Sarkar S, Wittmann G, Fekete C, Lechan RM (2004) Central administration of cocaine- and amphetamine-regulated transcript increases phosphorylation of cAMP response element binding protein in corticotropin-releasing hormone-producing neurons but not in prothyrotropin-releasing hormone-producing neurons in the hypothalamic paraventricular nucleus. Brain Res 999:181-192. https://doi. org/10.1016/J.BRAINRES.2003.11.062

Schaefer FJ, Wuertz S (2016) Insights into kisspeptin- and leptin-signalling on GnRH mRNA expression in hypothalamic organ cultures of immature pikeperch Sander lucioperca. Int Aquat Res 8:191-196. https://doi.org/10.1007/ s40071-016-0134-1

Schwartz MW, Seeley RJ, Campfield LA et al (1996) Identification of targets of leptin action in rat hypothalamus. J Clin Invest 98:1101-1106. https://doi.org/10.1172/JCI118891

Simon B, Wattler F, Merchant JL et al (1997) RAP1-like binding activity in islet cells corresponds to members of the Sp1 family of transcription factors. FEBS Lett 411:383388. https://doi.org/10.1016/S0014-5793(97)00736-9

Singh SK, Sundaram CS, Shanbhag S, Idris MM (2010) Proteomic profile of zebrafish brain based on two-dimensional gel electrophoresis matrix-assisted laser desorption/ionization MS/MS analysis. Zebrafish 7:169-177. https://doi. org/10.1089/zeb.2010.0657

Smith SM, Vaughan JM, Donaldson CJ et al (2004) Cocaine- and amphetamine-regulated transcript activates the hypothalamic-pituitary-adrenal axis through a corticotropin-releasing factor receptor-dependent mechanism. Endocrinology 145:5202-5209. https://doi.org/10.1210/en.2004-0708

Sohn J-W (2015) Network of hypothalamic neurons that control appetite. BMB Rep 48:229-233. https://doi.org/10. 5483/BMBREP.2015.48.4.272

Spier AD, de Lecea L (2000) Cortistatin: a member of the somatostatin neuropeptide family with distinct physiological functions. Brain Res Rev 33:228-241. https://doi.org/ 10.1016/S0165-0173(00)00031-X

St-Amand J, Yoshioka M, Tanaka K, Nishida Y (2012) Transcriptome-wide identification of preferentially expressed genes in the hypothalamus and pituitary gland. Front Endocrinol (lausanne) 2:111. https://doi.org/10.3389/fendo.2011.00111

Subhedar N, Barsagade VG, Singru PS et al (2011) Cocaineand amphetamine-regulated transcript peptide (CART) in the telencephalon of the catfish, Clarias gariepinus: distribution and response to fasting, 2-deoxy-D-glucose, glucose, insulin, and leptin treatments. J Comp Neurol 519:1281-1300. https://doi.org/10.1002/cne.22569

Takeuchi T, Ohtsuki Y (2001) Recent progress in T-cadherin (CDH13, H-cadherin) research. Histol Histopathol 16:1287-1293. https://doi.org/10.14670/HH-16.1287

Tan L, Peng H, Osaki M et al (2003) Egr-1 mediates transcriptional repression of COL2A1 promoter activity by interleukin-1 $\beta$. J Biol Chem 278:17688-17700. https:// doi.org/10.1074/jbc.M301676200

Team RDC (2013) R: a language and environment for statistical computing. Vienna: R Found Stat Comput
Thissen D, Steinberg L, Kuang D et al (2002) Quick and easy implementation of the Benjamini-Hochberg procedure for controlling the false positive rate in multiple comparisons. J Educ Behav Stat 27:77-83

Thornton JE, Cheung CC, Clifton DK, Steiner RA (1997) Regulation of hypothalamic proopiomelanocortin mRNA by leptin in $o b / o b$ mice. Endocrinology 138:5063-5066. https://doi.org/10.1210/endo.138.11.5651

Thottassery JV, Sun D, Zambetti GP et al (1999) Sp1 and Egr-1 have opposing effects on the regulation of the rat Pgp2/ mdr1b gene. J Biol Chem 274:3199-3206. https://doi.org/ 10.1074/jbc.274.5.3199

Unger JL, Glasgow E (2003) Expression of isotocin-neurophysin mRNA in developing zebrafish. Gene Expr Patterns 3:105-108. https://doi.org/10.1016/S1567-133X(02) 00064-9

Volkoff H (2016) The neuroendocrine regulation of food intake in fish: a review of current knowledge. Front Neurosci 10:540. https://doi.org/10.3389/fnins.2016.00540

Volkoff H, Peter RE (2001) Characterization of two forms of cocaine- and amphetamine-regulated transcript (CART) peptide precursors in goldfish: molecular cloning and distribution, modulation of expression by nutritional status, and interactions with leptin. Endocrinology 142:50765088. https://doi.org/10.1210/endo.142.12.8519

Wang Y, Botolin D, Xu J et al (2006) Regulation of hepatic fatty acid elongase and desaturase expression in diabetes and obesity. J Lipid Res 47:2028-2041. https://doi.org/10. 1194/jlr.M600177-JLR200

Wang B, Cui A, Wang P et al (2020) Temporal expression profiles of leptin and its receptor genes during early development and ovarian maturation of Cynoglossus semilaevis. Fish Physiol Biochem 46:359-370. https://doi.org/10. 1007/s10695-019-00722-6

Yang S, Liu T, Li S et al (2008) Comparative proteomic analysis of brains of naturally aging mice. Neuroscience 154:1107-1120. https://doi.org/10.1016/J.NEUROSCIEN CE.2008.04.012

Yu H, Iyer RK, Kern RM et al (2001) Expression of arginase isozymes in mouse brain. J Neurosci Res 66:406-422. https://doi.org/10.1002/jnr.1233

Yuan D, Zhang X, Wang B et al (2020) Effects of feeding status on nucb1 and nucb2A mRNA expression in the hypothalamus of Schizothorax davidi. Fish Physiol Biochem 46:1139-1154. https://doi.org/10.1007/s10695-020-00780-1

Yuan D, Wang B, Tang T, et al (2021) Characterization and evaluation of the tissue distribution of $\mathrm{CRH}$, apelin, and GnRH2 reveal responses to feeding states in Schizothorax davidi. Fish Physiol Biochem 1-18. https://doi.org/10. 1007/s10695-020-00922-5

Zhang X, Liu Y (2003) Suppression of HGF receptor gene expression by oxidative stress is mediated through the interplay between Sp1 and Egr-1. Am J Physiol Physiol 284:F1216F1225. https://doi.org/10.1152/ajprenal.00426.2002

Publisher's note Springer Nature remains neutral with regard to jurisdictional claims in published maps and institutional affiliations. 